Олег Колісник, кандидат психологічних наук, доцент Національний університет оборони України імені Івана Черняховського, м. Київ

ORCID ID 0000-0002-6208-9106

Кіра Горячева,

кандидат економічних наук, доцент

Військовий інститут Київського національного університету імені Тараса Шевченка, м. Київ ORCID ID 0000-0003-1503-4425

Олена Звоненко, кандидат юридичних наук

Військовий інститут Київського національного університету імені Тараса Шевченка, м. Київ

ORCID ID 0000-0002-4651-7449

Юлія Тітомир,

Військовий інститут Київського національного університету імені Тараса Шевченка, м. Київ ORCID ID 0000-0002-3704-6550

DOI: $10.33099 / 2617-1775 / 2020-02 / 154-165$

\title{
ТЕХНОЛОГІЗАЦЯ ПЕДАГОГІЧНИХ ПРОЦЕСІВ НА ОСНОВІ МЕТОДИКИ ПРОВЕДЕННЯ ГРУПОВИХ І ПРАКТИЧНИХ ЗАНЯТЬ У ВВНЗ ТА ВІЙСЬКОВИХ ПІДРОЗДІЛАХ
}

В статті висвітлюються особливості навчального процесу $i$ технологізації, тобто дотримання змісту $i$ послідовності навчально-виховних етапів; визначено особливості завдання у військових підрозділах, які містять у собі елементи проблемності, тобто створюються умови, за яких військовослужбовець відшукує з кількох неоднозначних рішень або відповідей одне правильне значення.

Зазначено, шо як у ВВНЗ та їх підрозділах, так $і$ у військах поширеним видом занять $\epsilon$ групове заняття. Цей вид занять проводиться з навчальною групою (підрозділом) $i$ має на меті детальний розгляд теоретичних питань, елементів практичної діяльності командирів і штабів під час вирішення завдань, а також під час вивчення зразків озброєння та бойової техніки. Характерною особливістю групового заняття $\epsilon$ застосування різного роду ілюстрацій (електронних посібників, плакатів, схем, стендів, зразків техніки та ін.). Викладення навчального матеріалу здійснюється у тісному зв'язку із завданнями фахової підготовки військовослужбовців. Виокремлено чотири періоди трансформащії змісту поняття від «технології в освіті» до «технології освіти». Конкретизовано класифікацію «технології навчання». Наголошено, щзо педагогічна технологія наближає педагогіку до точних наук, а педагогічну практику робить організованим, керованим прочесом з передбачуваними позитивними результатами.

Ключові слова: педагогічна практика; технологія навчання; педагогічний процес; педагогічна технологія; класифікація; практична спрямованість; навчально-виховні етапи.

Постановка проблеми. Однією iз суттєвих характеристик педагогічного процесу $є$ його технологізація - дотримання змісту і послідовності навчальновиховних етапів, що потребує особливої уваги до використання, розвитку i вдосконалення педагогічних технологій. Педагогічна технологія (грец. techne - 
майстерність i logos - слово, вчення) - сукупність психолого-педагогічних настанов, які визначають спеціальний підхід i композицію форм, методів, способів, прийомів, засобів (схем, креслень, діаграм, карт) у навчально-виховному процесі [1].

ЮНЕСКО трактує педагогічну технологію як системний метод створення, застосування процесу викладання і засвоєння знань з урахуванням технічних $\mathrm{i}$ людських ресурсів і їх взаємодії з метою оптимізації форм освіти.

Аналіз останніх досліджень і публікацій 3 проблеми, що розглядається у статті та означення аспектів загальної проблеми, яким присвячується стаття. Проблеми сучасного стану, цілі та зміст, проблеми технологізації педагогічних процесів на прикладі методики підготовки та проведення групових і практичних занять у ВВНЗ та військових підрозділах і $є$ предметом уваги науковців в галузі педагогічної науки, а також керівництва держави, командування Збройних Сил України, зокрема, С. Балашова, В. Рижиков, К. Горячева, В. Кожевніков, А. Романишин, С. Скрипник, Л. Снігур, О. Хижняк та ін.

Метою статті $\epsilon$ висвітлення особливостей технологізації педагогічних процесів на основі методики проведення групових і практичних занять у ВВНЗ та військових підрозділах.

Методи дослідження. У статті використано окремі загальнонаукові та спеціальні методи теоретико-емпіричного дослідження, зокрема аналіз наукової літератури із проблеми, систематизація та узагальнення матеріалів.

Виклад основного матеріалу дослідження 3 повним обгрунтуванням отриманих наукових результатів. Поняття "педагогічна технологія" дещо ширше від поняття "навчальна технологія", оскільки охоплює і виховні технології. У педагогічній літературі використовуються як тотожні поняття "технологія навчання" i "навчальна технологія". Побутує думка, що поняття "технологія навчання" $\epsilon$ дещо вужчим від поняття "навчальна технологія", оскільки поняття "технологія навчання" спонукає розглядати конкретну технологію, яка дає змогу добре навчати, тобто $\epsilon$ високоефективною, а поняття "навчальна технологія" $\epsilon$ менш цілеспрямованим і дає змогу розглядати різні технології навчання [1].

Термін «педагогічна технологія» з'явився в освіті порівняно недавно. Щодо навчального процесу його було вжито у 1886 р. англійцем Джеймсом Саллі (1842-1923). Однак дискусія з приводу того, чи існує в природі педагогічна технологія як певний інструмент навчання й виховання, яким може оволодіти кожний педагог, триває дотепер. У ній окреслилося дві принципові позиції. Прибічники однієї переконані, що виховання й навчання є творчими процесами, інтуїтивним осягненням світу іншої людини і відповідним впливом на цей світ, їх опоненти доводять, що педагогічний процес має інструментальний характер. Його мета полягає у вихованні особистості із заздалегідь заданими властивостями [2].

Одним із перших оприлюднив ідею технологізації навчального процесу видатний чеський мислитель-гуманіст, педагог, громадський діяч Ян-Амос Коменський (1592-1670), стверджуючи, що школа $є$ майстернею, «живою типографією», яка «друкує» людей. Учитель, на його думку, в педагогічному процесі користується тими засобами для виховання й освіти дітей, що й 
типографські працівники, створюючи книгу. Технологія навчального процесу, за переконаннями Я.-А. Коменського, повинна гарантувати позитивний результат навчання. Функціонально вона має бути своєрідною дидактичною машиною, яка, за умови правильного користування нею, забезпечувала б очікуваний результат. Для цього слід чітко окреслити цілі, вміло вибрати засоби, встановити жорсткі правила їх використання. Усе це свідчить, що Я.-А. Коменський розглядав технологізацію як важливий засіб впровадження провідних дидактичних принципів [2].

Концепція розвитку особистості американського гуманіста Карла Роджерса (1902-1987) основана на протиставленні когнітивного (засвоєння знань, розвиток особистості учня під неухильним контролем педагога) i дослідного (зорієнтованого на особистісний розвиток та емоційну сферу учня) типів навчання. За твердженням Роджерса, особистий досвід самоцінний для учня i тому є єдиним критерієм оцінювання життєвих подій. Учіння, у процесі якого особистість самостійно розвивається, приносить величезне задоволення, вирішально впливаючи на особистість людини.

Австро-німецький філософ i педагог, засновник антропософії Рудольф Штейнер (1861-1925) започаткував індивідуальний підхід до виховання дітей, який ліквідовував відокремлене навчання дівчаток i хлопчиків, поділ за соціальними прошарками, ступенем обдарованості i належності до різних віросповідань. Найважливішою проблемою людського мислення Штейнер вважав необхідність «зрозуміти людину як засновану на собі самій вільну особистість». На основі антропософії, яка вивчає людину в тілесному, душевному і духовному аспектах, він створив педагогіку, що охоплює розвиток і саморозвиток цілісної

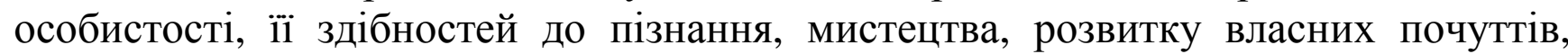
моральних задатків і релігійних переживань. Завдання педагога Штейнер вбачав у використанні технологій, що розвивають в особистості здатність до орієнтованих на різноманітність світу суджень i умовисновків. Саме цей принцип було покладено в основу навчання і виховання у першій Вільній вальдорфській школі.

Представники «педагогіки творчості» (Ф. Гансберг, Е. Лінде, Г. Шаррельман) засуджували спроби впливати на неповторну особистість дитини за допомогою технології. Будучи переконаними, що до кожної особистості дитини необхідно добирати індивідуальні засоби виховання, вони не визнавали ідеї і можливості створення педагогічної технології, яка могла б стати ключем до душі дитини.

На відмові від педагогічної технології як інструменту впливу на дитину грунтуються традиції «вільного виховання», які започаткували і розвивали в Росії Лев Толстой (1828-1910), Костянтин Вентцель (1857-1947), Луїза Шлегер (1863-1942) та ін. Вони заперечували можливість «технологізувати» педагогічний процес, пропагували ідею створення особливого дитячого світу, «пробудження душі дитини», прагнення зберегти в людині оригінальність i яскравість дитинства, а успішність чи неуспішність роботи навчального закладу оцінювали не на підставі використовуваних технологій, а зважаючи на творчу спрямованість особистості педагога, на створений ним клімат у процесі навчання й виховання. 
У колишньому Радянському Союзі педагогічні технології розглядали як засіб реалізації більшовицької ідеології, що надавало їм відповідної політичної заангажованості, вимагало врахування класових характеристик індивіда у процесі цілеспрямованої діяльності тощо. Зміст інформації свідомо добирали 3 орієнтацією на виховання комуністичної свідомості й моралі. Тобто педагогічні технології використовувались як засіб формування комуністичного світогляду і поведінки. Політично заангажовані вчені, педагоги-практики активно розпочали процес конструювання адекватних цим завданням технологій.

Однією $з$ перших була створена протягом 20-х років XX ст. педологія (грец. pais (paidos) - дитина i logos - слово, вчення) - комплексна наука про дитину, яка, за задумом іiі засновників, мала стати антропологічною базою педагогіки. Саме в наукових працях із педології, заснованих на рефлексології (М. Басов, В. Бехтерєв, О. Ухтомський, С. Шацький), вперше згадано термін «педагогічна технологія». Тоді розповсюджувалося й поняття «педагогічна техніка» сукупність прийомів і засобів, спрямованих на чітку й ефективну організацію навчальних занять. Елементами педагогічної технології вважали також уміння оперувати навчальним і лабораторним обладнанням, використовувати наочні посібники. Нормативні педагогічні знання виводили з педології і вибудовували за схемою, згідно 3 якою конкретні педагогічні впливи повинні відповідати конкретним умовам виховання і віковим особливостям дитини. Педагоги, які сповідували цей підхід, намагалися вивчати побутові, природні, соціальні й культурні чинники середовища, які зумовлювали розвиток дитини, іiі генетичні, фізіологічні, психологічні, соціальні характеристики як похідні від соціальних умов життя. 3 цією метою вони використовували тести, анкети, інтерв'ю, експерименти, життєві спостереження. Збагачення і розвиток життєвих уявлень, входження дітей у світ природи, праці і суспільних відносин сприяли оволодінню ними системою знань, цілісних уявлень, яких не давало i не могло дати навколишне мікросередовище. Згідно 3 концептуальним задумом педологів, беручи участь у суспільно корисній праці, змінюючи навколишнє середовище відповідно до здобутих у школі знань, умінь і навичок, діти перетворюють свій ціннісно-емоційний світ, оволодівають соціально значущими видами діяльності. Цей аспект педагогічної технології був високо оцінений відомими зарубіжними вченими (Д. Дьюї, В. Кілпатрік).

У 30-ті роки XX ст. розпочалася технологічна революція в освітній системі США. Протягом наступних десятиліть зазнало еволюції тлумачення терміна «педагогічна технологія», що породило дискусію про його сутність, структуру i джерела розвитку. Трансформація його змісту від «технології в освіті» до «технології освіти» охоплює чотири періоди.

1. 1940-1950 pp. У цей час з'явилися і впроваджувались у навчальний процес технічні засоби запису, відтворення звуку та проекції зображення, термін «технологія в освіті», який протягом наступних років під впливом праць із методики застосування різноманітних технічних засобів навчання модифікувався в термін «педагогічні технології». 
2. Середина 50-х - 60-ті роки. Протягом цього періоду педагогічна громадськість активно дискутувала щодо суті поняття «педагогічна технологія», внаслідок чого виокремилось два напрями його тлумачення, а відповідно, і суті педагогічної технології як феномену. Представники одного з них виступали за необхідність застосування аудіовізуальних (лат. audio - чую, слухаю i visualis зоровий) засобів і програмованого навчання (technology in education), прихильники іншого головним завданням вважали підвищення ефективності організації навчального процесу (technology of education), подолання відставання педагогічних ідей від стрімкого розвитку техніки. На цій підставі один напрям був означений як «технічні засоби у навчанні», другий, що виник дещо пізніше, 一 як «технологія навчання», або «технологія навчального процесу». Тоді у багатьох високорозвинутих країнах почали видавати спеціальні педагогічні часописи: у США - журнал «Педагогічна технологія» (1961), у Великій Британії (1964), Японії (1965) та Італії (1971) — «Педагогічна технологія і програмоване навчання». У 1967 р. в Англії було створено Національну раду з педагогічної технології, у США - Інститут педагогічної технології. У колишньому Радянському Союзі започатковано дослідження 3 алгоритмізації навчання (Л. Ланда). Педагогіка і психологія намагалися знайти раціональні для себе зерна в обгрунтованій філософією та соціологією концепції системного підходу в дослідженні соціальних, природних явищ і процесів.

3. 70-ті роки XX ст. У системі освіти розпочато модернізацію навчального обладнання і навчальних предметних середовищ як необхідної умови реалізації прогресивних методик і форм навчання. Утверджувалось тлумачення педагогічної технології як вивчення, розроблення та застосування принципів оптимізації навчальної діяльності на основі найновіших досягнень науки і техніки. Завдяки використанню основ інформатики, теорії телекомунікацій (грец. tele - далеко і лат. communicatio - зв'язок, повідомлення), педагогічної кваліметрії (галузі педагогічної науки, яка вивчає і реалізує методи кількісного оцінювання якості навчально-виховного процесу), системного аналізу та нових досягнень психологопедагогічної науки було значно розширено базу педагогічної технології. Тоді ж розпочато підготовку професіональних педагогів-технологів, масове використання таких технічних засобів навчання, як відеомагнітофон, карусельний кадропроектор, поліекран, електронна дошка, синхронізатори звуку та зображення тощо. Педагогіка почала використовувати можливості безмашинного програмування, набули популярності створені за принципом програмування посібники, зокрема 3 педагогіки.

4. 80-ті роки XX ст. - початок XXI ст. На цей період припало створення i розвиток мережі комп'ютерних лабораторій i дисплейних класів. Динамічно розвиваються програмовані, інтерактивні засоби навчання, тривають різноманітні дослідження теоретичних питань педагогічної технології та шляхів іiї практичного впровадження.

Запропонована періодизація вибудовується на таких конкретних фактах:

1946 р. - обгрунтування плану аудіовізуальної освіти в університеті штату Індіана США. 
1954 р. - обгрунтування ідеї програмованого навчання.

1961 р. — відкриття факультету технології навчання в університеті Південної Кароліни.

1968 р. - розроблення і застосування мови програмування ЛОДО в школі (Масачусетський технологічний інститут США).

1976 р. - створення першого персонального комп'ютера.

1981 p. - застосування у навчанні спеціальних програмованих засобів у дисплейних класах.

1990 р. - використання інтерактивних технологій в освіті.

Історію становлення педагогічної технології певною мірою відтворює така схема: задум упровадити інженерний підхід («інженерна педагогіка») $\rightarrow$ технічні засоби в навчальному процесі $\rightarrow$ алгоритмізація навчання $\rightarrow$ програмоване навчання $\rightarrow$ технологічний підхід $\rightarrow$ педагогічна технологія (дидактичний аспект) $\rightarrow$ поведінкова технологія (аспект виховання). Не всі складові педагогічної технології набули однакового розвитку. Особливо складним $\epsilon$ створення технології виховання, хоча й ця галузь має вагомі напрацювання.

Загалом, технологія як феномен є важливою складовою історії людства, формою вираження інтелекту, сфокусованого на розв'язанні важливих проблем буття, синтезом розуму і здібностей людини.

Педагогічна технологія повинна задовольняти такі методологічні вимоги:

- концептуальність (кожній педагогічній технології повинна бути притаманна опора на певну наукову концепцію, яка забезпечує філософське, психологічне, дидактичне і соціально-педагогічне обгрунтування досягнення освітніх цілей);

- системність (педагогічна технологія повинна мати всі ознаки системи: логіку процесу, взаємозв'язок усіх його частин, цілісність);

- керованість, яка передбачає діагностичне планування, проектування процесу навчання, поетапну діагностику, варіювання засобами і методами з метою корекції результатів;

- ефективність (педагогічні технології існують у конкретних умовах і повинні бути ефективними за результатами і оптимальними витратами, гарантувати досягнення певного стандарту навчання);

- відтворюваність, що уможливлює застосування (повторення, відтворення) педагогічної технології в інших однотипних освітніх установах іншими суб'єктами.

У сучасній дидактиці представлені найрізноманітніші технології навчання. Їх різноманіття пов'язано 3 тим, що кожен автор i виконавець приносять в педагогічний процес щось своє, індивідуальне, тим самим змінюючи технологію.

Технології навчання класифікують:

а) за рівнем застосування: загально-дидактичні, особисто-методичні (предметні) і локальні (модульні);

б) на філософській основі: наукові та релігійні, гуманістичні та авторитарні;

в) 3 наукової концепції засвоєння досвіду: асоціативно-рефлекторні, Біхевіористичні, інтеріоризаторські, розвиваючі; 
г) $з$ орієнтації на особистісні структури: інформаційні (формування знань, умінь і навичок), операційні (формування способів розумових дій), евристичні (розвиток творчих здібностей), прикладні (формування дієво-практичної сфери);

д) 3 характеру модернізації традиційної системи навчання: технологї по активізації і інтенсифікації діяльності учнів; технології на основі гуманізації i демократизації відносин між вчителем і учнями; технології на основі дидактичної реконструкції навчального матеріалу та ін.

До основних методичних документів для проведення групового заняття відносять методичну розробку (методичні вказівки), план проведення заняття або план конспект.

Організація вивчення нового навчального матеріалу 3 навчальною групою (підрозділом) дозволяє керівнику заняття глибоко i конкретно розкрити його сутність, наочно показати застосування теорії у розв'язанні різноманітних практичних завдань, здійснювати постійний зворотний зв'язок iз військовослужбовцями. Під час заняття керівник може звертатися безпосередньо до конкретного військовослужбовця 3 метою з'ясування: як сприймається навчальний матеріал, що саме зрозуміло для нього, а що потребує додаткового пояснення або навіть зміни методики викладання того чи іншого навчального питання. Для цього керівник ставить перед групою чи перед окремим військовослужбовцем запитання, які б змусили їх (його) застосувати викладену теорію для вирішення завдань, що відрізняються від типових. Досвід показує, що вміле використання цього методичного прийому керівником заняття забезпечує активну роботу військовослужбовців на занятті та глибоке засвоєння ними змісту навчальних питань. Для закріплення та перевірки розуміння навчального матеріалу в кінці заняття керівник може дати військовослужбовцям завдання практичної спрямованості або летючку.

Групова форма проведення практичного заняття надає можливість:

- виконання завдань практичної роботи у невеликих за складом групах курсантів;

- під час проведення практичної роботи досягнення загальної мети відбувається спільними зусиллями членів групи;

- така діяльність не ізолює курсантів один від одного, а навпаки, дає змогу реалізувати природне прагнення до спілкування, взаємодопомоги i сприяє поглибленню знань, виробленню та закріпленню умінь та навичок;

- у процесі групової діяльності зникає страх спілкування з викладачем;

- завдання практичної роботи виконується індивідуально, але 3 взаємодопомоги курсантів;

- виникає можливість вчитися один в одного;

- покращується контроль і корекція знань, адже курсанти запитують один одного, разом працюють над виконанням завдань i вправ, перевіряють правильність виконання;

- викладач оцінює результати навчання кожного члена групи.

У закріпленні та поглибленні знань, набутті умінь щодо вирішення практичних завдань військовослужбовцями за їхнім призначенням значне місце 
посідають практичні заняття [4]. Практичні заняття забезпечують активне формування та розвиток у військовослужбовців навичок і якостей, необхідних їм у виконанні службових обов'язків.

Залежно від специфіки предметів навчання практичні заняття умовно розподіляють на дві групи. До першої групи відносять заняття, на яких вирішують завдання, виконують розрахунки, графічні та інші роботи, відпрацьовують документи. До другої групи відносять заняття, пов'язані з оволодінням прийомами роботи з технікою, методикою аналізу конструктивних і схемних вирішень та ін.

Будь-яке практичне заняття розпочинається 3 формування цільової настанови. Розуміння військовослужбовцями мети та завдання заняття, його значення для їх фахової підготовки сприяє як підвищенню інтересу до заняття, так i активізації роботи з оволодіння навчальним матеріалом [5].

Після цього здійснюється короткий огляд теоретичних положень, які $\epsilon$ основою для відпрацювання навчальних питань на даному занятті. Як правило, це вирішується методом усного опитування або у вигляді летючки, i, як результат, керівник заняття здійснює контроль повноти та якості засвоєння навчального матеріалу. Узагальнення теоретичного обгрунтування даного заняття може доручатись одному із військовослужбовців. Але перед призначенням його для доповіді завдання ставиться всьому підрозділу, і тільки після деякої паузи призначається військовослужбовець для відповіді. Такий прийом сприяє більш активній діяльності групи на занятті та є додатковим стимулом для іiі самостійної роботи. Дуже часто молоді керівники занять не дають оцінки правильності відповіді, а інколи, коли вона неправильна, переривають військовослужбовця i самі відповідають на поставлене питання. 3 методичної точки зору це неправильно. За будь-яких обставин він повинен обов'язково оцінити відповідь військовослужбовця, а якщо потрібно - уточнити і дати правильне формулювання теоретичного положення [8].

Основою практичного заняття $є$ робота військовослужбовців 3 виконання навчальних завдань під керівництвом керівника. Ефективність ії залежить від ряду умов. По-перше, необхідно ретельно відпрацювати навчальні завдання. Кожне завдання за своїм змістом повинно логічно розвивати основну ідею предмета навчання та враховувати спрямованість фахової підготовки військовослужбовців. По-друге, у завданні необхідно передбачати використання та закріплення знань, умінь, навичок, отриманих під час вивчення суміжних предметів, тобто враховувати принцип комплексності у навчанні.

Висновки. Кожна педагогічна технологія може бути ефективною за умови психологічної обгрунтованості, практичної спрямованості. Розроблення i застосування будь-якої педагогічної технології вимагає творчої активності педагогів і учнів, залучення їх до творчої участі в розробленні технологічного інструментарію: складання технологічних схем, карт, організації технологічних форм виховання і навчання. Активність педагога виявляється у глибокому знанні психологічних особливостей учнів, внесенні коректив у розгортання технологічного процесу, організації взаємних консультацій, взаємоперевірки i взаємооцінки. 
Результат педагогічної технології залежить від рівня майстерності педагога, його загального розвитку, загального психологічного клімату в колективі, матеріально-технічного оснащення, настроєності учнів.

\section{ЛІТЕРАТУРА}

1. Горячева К.С. Методика впровадження дидактичних та рольових ігор в освітній процес військової освіти як практика прийняття рішень в умовах обстановки наближеної до бойової // Горячева К.С., Рижиков В.С. // Молодь і ринок. - Дрогобич, 2018. - Вип. № 7 (162). - С.17 - 22.

2. Алексюк А. М. Педагогіка вищої школи України. Історія. Теорія: підручник / А. М. Алексюк. - К.: Либідь, 1998. - 558 с.

3. Балашова С.П. Практичний курс військової психології: Навчальний посібник. Частина 2. / Балашова С.П., Васильєв С.П., Дубровинський Г.Р.- К.: Київський національний університет імені Тараса Шевченка, 2013. - 172 с.

4. Беспалько В. П. Педагогика и прогрессивные технологии обучения / В. П. Беспалько. - М. : Ин-т ПО М-ва образования России, 1995. - 208 с.

5. Військова педагогіка у професійній діяльності офіщера і сержанта: навчальний посібник. Частина II. Методика та системи виховання військовослужбовців / [О.В. Бойко, Л.В. Коберський, В.М. Кожевніков, А.М. Романишин, С.В. Скрипник] - Львів : АСВ, 2012. - 382 с.

6. Військова психологія і педагогіка : [підручник / авт. кол-в Л. А. Снігур, О. А. Хижняк, Є. М. Подтергера, Е. І. Сарафанюк, К. П. Аветісян, О. Ю. Булгакова] ; за заг. ред. Л. А. Снігур. - Луцьк: ПВД «Твердиня», 2010. - 576 с.

7. Гальперин П.Я. Формирование знаний и умений на основе теории поэтапного усвоения умственных действий / П. Я. Гальперин, Н. Ф. Талызина. - М.: МГУ, 1970. - 180 с.

8. Нещадим I. М. Військова освіта України: історія, теорія, методологія, практика: Монографія /I.М.Нещадим//. - К., 2003.- 766 с.

9. Про вищу освіту: Закон України від 1 липня 2014 року № 1556-VII (Відомості Верховної Ради (ВВР), 2014, № 37-38, ст.2004)

10. Про Збройні Сили України: Закон України № 2019-ІІІ від 05.10.2000р. // Відомості Верховної Ради України [Текст].—2000.—№ 48. - Ст. 410.

11. Про особливості організації освітнього процесу у вищих військових навчальних закладах Міністерства оборони України та військових навчальних підрозділах вищих навчальних закладів України: Положення. Наказ Міністерства оборони України № 346 від 20.07.2015 Зареєстровано в Міністерстві юстиції України 22 вересня 2015 р. за № 1126/27571 (Нормативний документ Міністерства оборони України. Наказ. Положення). Адреса доступу http://zakon3.rada.gov.ua/laws/show/z1126-15/page

12. Komenski I.A. Wielika dydaktika. - Wroclaw: Ossolineum, 1956. - 86 p.

\section{REFERENCES}

1. Horiacheva K.S. Methods of introducing didactic and role-playing games in the educational process of military education as a practice of decision-making in a situation close to combat // Horiacheva K., Ryzhykov V. // Youth and the market. - Drogobich, 2018. - Ed. №7 (162) - P. 17-22.

2. Aleksyuk A.M. Pedagogy of the higher school of Ukraine. History. Theory: Textbook / AM Aleksyuk. - K .: Lybid, 1998. - 558 p.

3. Balashova S.P. Practical course of military psychology: Textbook. Part 2. / Balashova S.P., Vasiliev S.P., Dubrovynsky G.R. - K.: Kyiv National Taras Shevchenko University, 2013. - 172 p.

4. Bespalko V.P. Pedagogy and progressive learning technologies / V.P. Bespalko. M.: Institute of Software of the Ministry of Education , 1995. - 208 p.

5. Military pedagogy in the professional activities of officers and sergeants: Textbook. Part II. Methods and systems of education of servicemen / O.B. Boyko, L.V. Kobersky, V.M. Kozhevnikov, A.M. Romanishin, S.V. Skrypnyk - Lviv: DIA, 2012. - 382 p. 
6. Military psychology and pedagogy: Textbook / Ed. team L.A. Snigur, O.A. Khyzhnyak, E.M. Podterger, E.I. Sarafanyuk, K.P. Avetisyan, O. Y. Bulgakova; for general ed. L. A. Bullfinch. - Lutsk: PVD "Tverdynya", 2010. - 576 p.

7. Galperin P.Y. Formation of knowledge and skills based on the theory of step-by-step assimilation of mental actions / P.Y. Galperin, N.F. Talyzina. - M.: MSU, 1970. - 180 p.

8. Neschadym I.M. Military education of Ukraine: history, theory, methodology, practice: Monograph / I.M. Neschadym - K., 2003.- 766 p.

9. On Higher Education: Law of Ukraine of July 1, 2014 № 1556-VII (Information of the Verkhovna Rada (VVR), 2014, № 37-38, Article 2004)

10. On the Armed Forces of Ukraine: Law of Ukraine № 2019-III of 05.10.2000 // Bulletin of the Verkhovna Rada of Ukraine [Text]. - 2000. - № 48. - P. 410.

11. On the peculiarities of the organization of the educational process in higher military educational institutions of the Ministry of Defense of Ukraine and military educational subdivisions of higher educational institutions of Ukraine: Regulations. Order of the Ministry of Defense of Ukraine № 346 dated 20.07.2015 Registered with the Ministry of Justice of Ukraine on September 22, 2015 under № 1126/27571 (Normative document of the Ministry of Defense of Ukraine. Order. Regulations). Access address http://zakon3.rada.gov.ua/laws/show/z1126-15/page

12. Komenski I.A. Wielika dydaktika. - Wroclaw: Ossolineum, 1956. - 86 p.

\section{РЕЗЮМЕ}

Олег Колесник,

кандидат психологических наук, доцент Национальный университет обороны Украины имени Ивана Черняховского

Кира Горячева, кандидат экономичных наук, доцент Военный институт Киевского национального университета имени Тараса Шевченко

Елена Звоненко,

кандидат юридических наук Военный институт Киевского национального университета имени Тараса Шевченко

Юлия Титомир,

Военный институт Киевского национального Университета имени Тараса Шевченко

\section{Технологизация педагогических процессов на основе методики проведения групповых и практических занятий в ВВУЗ и воинских подразделениях}

В статье освещуаются особенности учебного процесса и технологизации, то есть соблюдение содержания и последовательности учебно-воспитательных этапов, а так же определены особенности задачи в военных подразделениях, содержащие в себе элементы проблемности, то есть создаются условия, при которых военнослужащий ищет по нескольким неоднозначным решениям или ответам одно правильное значение.

Отмечено, что как в вузах, их подразделениях, так и в войсках распространенным видом занятий является групповое занятие. Этот вид занятий проводится с учебной группой (подразделением) и имеет целью детальное рассмотрение теоретических вопросов, элементов практической деятельности командиров и штабов при решении задач, а также при изучении образиов вооружения и боевой техники. Характерной особенностью группового занятия является применение различного рода иллюстраций (электронных пособий, плакатов, схем, стендов, образиов техники и др.). Изложение учебного материала осуществляется в тесной связи с задачами профессиональной подготовки военнослужащих. Выделены четыре периода 
трансформаџии содержания понятия от «технологии в обучении» $\kappa$ «технологии обучения». Конкретизирована классификачия «технологии обучения». Отмечено, что педагогическая технология приближает педагогику к точным наукам, а педагогическую практику делает организованным, управляемым прочессом с предполагаемыми положительными результатами.

Обращено внимание на то, что на практических занятиях есть все условия для внедрения индивидуального обучения. Это объясняется тем, что руководитель имеет возможность наблюдать за работой каждого военнослужащего, изучать их индивидуальные особенности, своевременно оказывать помощь в решении сложных задач. Вместе с тем военнослужащим, которые успешно выполняют задания, руководитель может дать дополнительные задания, $a$ тем кто отстает, уделить больше внимания как на занятии, так и во внеучебное время.

Практические занятия отличаются от других видов занятий тем, что основным их содержанием является овладение приемами работь с вооружением и техникой. Они проводятся, как правило, в полевых условиях и в учебных лабораториях, на полигонах. Для оказания помощци руководителю занятия могут привлекаться офицеры и заранее подготовленные инструкторы. Главной задачей этих специалистов является контроль за действиями военнослужащих, выполнением ими мер безопасности и оказания помощи $в$ овладении определенными приемами работы с техникой.

Ключевые слова: педагогическая практика; технология обучения; педагогический процесс; педагогическая технология; классификаџия; практическая направленность; учебновоспитательные этапь.

\section{SUMMARY}

\section{Oleh Kolisnyk, Candidate of Psychological Sciences, Associate Professor National University of Ukraine named after Ivan Chernyakhovskyi \\ Kira Horiacheva, Candidate of Economics Sciences, Associate Professor Military institute of the Kiev national Taras Shevchenko university \\ Olena Zvonenko, \\ Candidate of Law Sciences Military institute of the Kiev national \\ Taras Shevchenko university Julia Titomir, Military institute of the Kiev national \\ Taras Shevchenko university}

Technologization of pedagogical processes based on the methodology of conducting group and practical classes in the higher educational institutions and military units

Introduction. The article highlights the features of the educational process and technology, ie compliance with the content and sequence of educational stages; the peculiarities of the task in military units are determined, which contain elements of problems, ie conditions are created under which a serviceman finds one correct meaning from several ambiguous decisions or answers.

It is noted that both in universities and their units, and in the army, a common type of training is group training. This type of training is conducted with a study group (unit) and aims to consider in detail the theoretical issues, elements of practical activities of commanders and staffs in solving problems, as well as in the study of samples of weapons and military equipment. A characteristic feature of the group lesson is the use of various illustrations (electronic manuals, posters, diagrams, stands, samples of equipment, etc.).

Purpose. Teaching material is carried out in close connection with the tasks of professional training of servicemen. There are four periods of transformation of the content of the concept from 
"technology in education" to "technology of education". The classification of "learning technology" is specified. It is emphasized that pedagogical technology brings pedagogy closer to the exact sciences, and makes pedagogical practice an organized, managed process with predictable positive results.

Methods. The article uses some general scientific and special methods of theoretical and empirical research, including analysis of the scientific literature on the problem, systematization and generalization of materials.

Results. The organization of the study of new educational material with the training group (unit) will allow the head of the lesson to deeply and concretely reveal its essence, clearly show the application of theory in solving various practical problems, to provide constant feedback to servicemen. Modern didactics presents a variety of learning technologies. Their diversity is due to the fact that each author and performer brings to the pedagogical process something of their own, individual, thereby changing the technology..

Conclusion. The practical component is the introduction of interactive forms of education namely business and role-playing games in the educational process of military educational institution, which bring theoretical training as close as possible to real practice, because business and roleplaying games are the basis of decision-making both in specific combat situations and in classes, they contribute to the formation of knowledge, laws, trends in military affairs, logical methods of system analysis. Role-playing techniques such as behavioral-game techniques are very important, they are based on stimulating the game interactions of cadets in close proximity to the real professional military combat activities of an officer. Such techniques include: instruction, activation of game parties, correction of the game participants behavior, step and final evaluation techniques. The socalled cognitive-game techniques are of particular importance in the organization of role-playing games in the military training. Such techniques include: a) techniques that promote entry into the role - image (description of each participant role in the game, motivation, encouragement, question-hint, as well as encouragement and humor); b) methods of role correlation (leading questions, comments questions, support - defence etc.).

Key words: pedagogical practice; learning technology; pedagogical process; pedagogical technology; classification; practical orientation; educational stages. 